DOI: $10.14451 / 2.122 .54$

\title{
ТЕКУЩЕЕ СОСТОЯНИЕ И ТЕНДЕНЦИИ РАЗВИТИЯ ТАРИФНОЙ ПОЛИТИКИ ЖИЛИЩНО-КОММУНАЛЬНЫХ ОРГАНИЗАЦИИ В МУНИЦИПАЛЬНОМ ОБРАЗОВАНИИ
}

\author{
(c) 2018 Шабанова Мадина Мухидиновна \\ доктор экономический наук, профессор \\ кафедра государственного и муниципального управления \\ Дагестанский государственный технический университет \\ 367015, г. Махачкала, пр. И. Шамиля, 70а \\ (C) 2018 Атуева Энара Бадурсултановна \\ кандидат экономических наук, доцент \\ кафедра государственного и муниципального управления \\ Дагестанский государственный технический университет \\ 367015, г. Махачкала, пр. И. Шамиля, 70а \\ (c) 2018 Дусилаева Хажибати Магомедовна \\ кафедра государственного и муниципального управления \\ Дагестанский государственный технический университет \\ 367015, г. Махачкала, пр. И. Шамиля, 70а \\ E-mail: fgimu_gimu@mail.ru
}

Особенно актуальными для урбанизированных территории, где разветвлённая сеть инженерной инфраструктуры, является проблема жилищно-коммунального хозяйства. Проведенный в статье анализ показал, что в данной сфере городской жизни остается достаточно много нерешенных проблем. На сегодняшний день, регулирование тарифной политики требует решения вопроса о том, как сделать коммунальные услуги доступными для населения муниципального образования, не нанося при этом ущерба интересам поставщиков услуг. Именно с этих позиций должен решаться вопрос повышения эффективности тарифной политики жилищно-коммунальных организаций и выбора формы взаимоотношений между потребителями, поставщиками и администрацией города Махачкалы, обязанной координировать и регулировать эти отношения, не допуская ущемления интересов сторон.

Ключевые слова: жилищно-коммунальный комплекс, жилищный комплекс, коммунальное хозяйство, инфраструктура, тарифная политика.

Развитие и реформирование жилищно- коммунальной сферы становится одним из главных направлений формирования устойчивой городской среды. В связи с этим в городе Махачкала необходимо решить проблемы, препятствующие стабильному и устойчивому развитию жилищно-коммунального сектора.

В Махачкале осуществлялись крупные проекты, в период с 2012-2016 гг.- это реконструкция магистралей по линии проспектов Насрутдинова, Гамзатова, улицы Гаджиева и 20 других улиц с полной заменой инженерных коммуникаций, строительство путепровода.

Стихийные свалки, являются одной из ключевых проблем в г. Махачкале и г. Каспийске, оказывающие негативное воздействие практически на все компоненты природной среды.
Одновременно крайне остро стоит проблема завершения канализационного тоннеля от Махачкалы до Каспийска, увеличения мощности очистных сооружений.

Как видно из данных, приведенных в табл. 1 на сегодняшний день, нуждаются в замене 123696 м. тепловых и паровых сетей, 211800 м. водопроводных сетей, 4590м. газовых сетей.

Реформирование жилищно-коммунального комплекса города ведется недостаточно эффективно. $43 \%$ предприятия жилищно-коммунального комплекса города являются убыточными.

Долг перед поставщиками газа у предприятий и населения города составил 200 млн. рублей. Задолженность за потребленную электроэнергию превысил 20млн. рублей.

При проведении опроса населения, срочный 
Таблица 1. Сведения об объектах коммунальной инфраструктуры в городе Махачкала по состоянию на 1 января 2017 года

\begin{tabular}{|l|l|l|}
\hline $\begin{array}{l}\text { Количество предприятий по утилизации и переработке бытовых } \\
\text { и промышленных отходов }\end{array}$ & ед. \\
\hline Вывезено за год твердых бытовых отходов & тыс.куб. м. & 1000 \\
\hline Одиночное протяжение уличной газовой сети & м & 1185280 \\
\hline в том числе нуждающейся в замене и ремонте & м & 4590 \\
\hline заменено и отремонтировано уличной газовой сети за отчетный год & м & 4590 \\
\hline Число источников теплоснабжения & ед. & 151 \\
\hline из них мощностью до 3 Гкал/ч & ед & 127 \\
\hline Протяженность тепловых и паровых сетей в двухтрубном исчислении & м & 259740 \\
\hline в том числе нуждающихся в замене & м & 123696 \\
\hline $\begin{array}{l}\text { протяженность тепловых и паровых сетей, которые были заменены и отре- } \\
\text { монтированы за отчетный год. }\end{array}$ & м & 21350 \\
\hline Одиночное протяжение уличной водопроводной сети & м & 494200 \\
\hline в том числе нуждающейся в замене & м & 211800 \\
\hline $\begin{array}{l}\text { одиночное протяжение уличной водопроводной сети, которая заменена и от- } \\
\text { ремонтирована за отчетный год. }\end{array}$ & м & 3300 \\
\hline Одиночное протяжение уличной канализационной сети & м & 134600 \\
\hline в том числе нуждающейся в замене & м & 75900 \\
\hline $\begin{array}{l}\text { одиночное протяжение уличной канализационной сети, которая заменена } \\
\text { и отремонтирована за отчетный год }\end{array}$ & м & 300 \\
\hline
\end{tabular}

ремонт, по мнению респондентов требуется:

- Система водоснабжения (Ленинский район-15\%, Кировский район $-25 \%$, Советский рай$\mathrm{OH}-9 \%)$;

- Ремонт лестничных проемов (Ленинский район-6\%, Кировский район-25\%, Советский район-18\%);

- Канализация (Ленинский район-22\%, Кировский район-6\%, Советский район-9\%);

- Система отопления (Ленинский район-15\%, Кировский район-20\%, Советский райOH-27\%)

- Капитальный ремонт всего жилого фонда (Ленинский район-26\%, Кировский район-25\%, Советский район-36\%)

Предложения по совершенствованию оплаты услуг населением, содержащиеся в правительственных документах по коммунальной реформе, основываются на убеждении о том, что жилищно-коммунальные услуги ничем не отличаются от частных товаров. И поэтому предусматривается переход на полную оплату коммунальных услуг всеми категориями потребителей при условии обеспечения социальной защиты малообеспеченных граждан. Практика дотаций предприятий жилищно-коммунального хозяйства должна быть заменена адресными жилищными субсидиями, устанавливаемые на основе единого показателя для получения жи- лищных субсидий - доли расходов на оплату жилищно-коммунальных услуг в совокупном доходе семьи. С последующим их зачислением на персонифицированные счета граждан. Федеральным стандартом этот показатель определен на уровне в 22\%. При этом субъекты РФ могут понижать его для отдельных категорий домохозяйств за счет собственных средств.

Предполагается введение государственного регулирования тарифов на услуги естественных монополий (поставка электроэнергии и природного газа) и ежегодное установление федеральным законом предельной стоимости ЖКУ на один м2 жилой площади дифференцированно по субъектам РФ. Установление тарифов должно обеспечивать покрытие текущих затрат эксплуатирующих организаций и затрат на ремонты. что предполагает создание эффективных механизмов целевого использования таких составляющих тарифа, как амортизационные отчисления и прибыль, на цели модернизации и развития. Соблюдение этого условия содержание жилищного фонда и систем инженерного обеспечения муниципальных образований станет мотивацией для частных инвестиций в эту сферу и прежде всего в тепло- и водоснабжение с имеющимися там большими возможностями роста экономической эффективности за счет ресурсосберегающих технологий и управлен- 
ческих решений. При этом предусматривался переход с бюджетной (в основном) на заемную основу инвестирования отраслей ЖКК (концессионные механизмы) с частичным бюджетным софинансированием.

В настоящее время система управления объектами инженерной инфраструктуры и тарифного регулирования не позволяет привлечение частных инвесторов в коммунальную инфраструктуру. Она не заинтересовывает предприятия ЖКХ в снижении затрат. В последние годы нельзя утверждать, что условия для частного инвестирования существенно улучшились. Главное здесь, что действует ограничение на рост тарифов и установление предельной стоимости ЖКУ на один м2 жилой площади. Проблемой государственно-частного партнерства в сфере жилищно-коммунального хозяйства можно считать определение тарифов на период времени в один год. Это ограничивает деятельность частных инвесторов. Отсутствие информации о доходах будущих периодов не позволяет использовать заемные средства для проектов по модернизации и реконструкции основных фондов жилищного и коммунального хозяйства.

Действующая система расчетов затрат существенно усложняет планирование осуществления проектов ГЧП, так как она ориентирована на такие нормативы, которые реально расходятся как со сложившимися, так и с необходимыми затратами. Поэтому структуры затрат, учитываемые в тарифе и в реальности, могут быть различны. Так, нормативные потери воды в водоснабжении больше, чем фактические. Это обуславливает установление тарифа, который не согласуется с реальной структурой затрат предприятия. В этом случае необходим для предприятия ЖКХ поиск дополнительных доходов, при росте потребность в финансировании затрат по другим позициям. В результате тарифное регулирование превращается в игру «кто кого перехитрит».

Практика тарифного регулирования, таким образом, не обеспечивает приток внебюджетных средств для финансирования инноваций в сфере жилищно-коммунального хозяйства. При наличии проработанного инвестиционного проекта не снимается основной риск инвестирования в коммунальную инфраструктуру, который связан с существующей системой тарифного регулирования: интересы потенциальных инвесторов не учитываются при установлении тарифов, сами процедуры тарифного регулирования непрозрачны и непонятны потенциальному инвестору.

В Федеральных законах «O водоснабжении и водоотведении» и «О теплоснабжении» предусмотрена возможность установления долгосрочных тарифов по методу RAB (метод доходности инвестированного капитала или индексации), применение которого Применение этих методов дает возможность предприятиям оставлять в своем распоряжении средства, полученные ими в результате снижения затрат вследствие повышения эффективности деятельности. Однако, на сегодняшний день, не приняты подзаконные нормативные акты, регламентирующие процедуру установления долгосрочных тарифов, и на практике в сфере жилищно-коммунального хозяйства подобные тарифы не установлены.

Еще одной серьезной проблемой, препятствующей развитию государственно-частного партнерства или муниципально-частного партнерства, является существующая практика разделения полномочий между органами местного самоуправления и регионами. Федеральным законом № 131 «Об общих принципах организации местного самоуправления в Российской Федерации» организация в границах поселения (городского округа) электро-, тепло-, газо- и водоснабжения населения, водоотведения возложена на органы местного самоуправления поселения (городского округа). Логической реализацией этого положения должно было быть наделение муниципалитета полномочием по утверждению тарифов на жилищно-коммунальные услуги. Но в соответствии с действующим законодательством утверждение тарифов на холодную и горячую воду, тепловую энергию и тарифов на подключение к системам коммунальной инфраструктуры является компетенцией органов исполнительной власти субъектов Российской Федерации. А учитывая, что при заключении договора государственно-частного партнерства одной из сторон договора является публичная власть, в данном случае, муниципалитет, то лишение его этих полномочий осложняет реализацию инвестиционных проектов, ухудшая инвестиционный климат жилищно-коммунального хозяйства муниципального образования.

Привлечение частных инвестиций и развитие муниципально-частного партнерства одно 
из главных направлений повышения экономической эффективности тарифной политики жилищно-коммунальных организаций муниципального образования «город Махачкала». В настоящее время в Республике Дагестан только прорабатываются возможности развития государственно-частного партнерства с применением механизма концессии.

Успех проекта муниципально-частного партнерства в большой степени зависит от того, способен ли муниципалитет предоставить гарантии предсказуемой и прозрачной тарифной политики на своей территории.

В направлении модернизации систем коммунальной инфраструктуры, повышения эффективности их управления и улучшения качества и надежности поставки коммунальных ресурсов необходимо проведение следующих мероприятий:

- обеспечение приемлемости тарифов для потребителей коммунальных услуг, что напрямую связано с социальной политикой муници- палитета;

- сокращение бюджетных расходов на ЖКХ, в том числе за счет привлечения внебюджетных источников финансирования инвестиционных программ муниципальных жилищно-коммунальных организаций;

- повышение инвестиционной привлекательности жилищно-коммунальных организаций;

- стимулирование жилищно-коммунальных организаций к внедрению практик ресурсосбережения и повышение качества оказываемых услуг;

- стимулирование потребителей к рациональному и экономному потреблению коммунальных услуг.

Реализация данных мероприятий позволит повысить эффективность функционирования жилищно-коммунального комплекса города и будет способствовать повышению уровня и качества городской среды.

\section{Библиографический список}

1. О государственно-частном партнерстве, муниципально-частном партнерстве в Российской Федерации и внесение изменений в отдельные законодательные акты Российской Федерации». Федеральный закон от 13 июля 2015 г. № 224-ФЗ.

2. «О концессионных соглашениях». Федеральный Закон от 21.07.2005 г. № 115

3. Концепция федеральной целевой программы «Комплексная программа модернизации и реформирования жилищно-коммунального хозяйства на 2010-2020 годы»: Распоряжение Правительства РФ от 02.02.2010 № 102-p.

4. Сведения об объектах инфраструктуры муниципального образования [электронный ресурс] режим доступа http://www.mkala.ru

5. Атуева Э.Б., Исалова М.Н., Шабанова М.М. Повышение эффективности функционирования коммунального хозяйства на основе использования механизмов муниципально-частного партнерства // Вестник Дагестанского государственного технического университета. Технические науки. 2016. № 43(4). С. $167-174$.

6. Шабанова М.М., Алиев Р.Д., Атуева Э.Б. Основы государственного и муниципального управления. Махачкала. 2015.290 с.

7. Шакиров Т.А. Тарифное законодательство как основной барьер для привлечения частных инвестиций в коммунальный сектор // Имущественные отношения в РФ. 2013. № 7 (142). 